Molecular and Cellular Endocrinology, 8 (1977) 291-299

c) Elsevier/North-Holland Scientific Publishers, Ltd.

\title{
STEROID AND FSH ACTION ON LH RECEPTORS AND LH-SENSITIVE TESTICULAR RESPONSIVENESS DURING SEXUAL MATURATION OF THE RAT *
}

\author{
Yii-Der Ida CHEN **, Michael J. SHAW and Anita H. PAYNE ${ }^{\dagger}$ \\ Steroid Research Unit, Departments of Obstetrics and Gynecology and Biological Chemistry, \\ University of Michigan, Ann Arbor, Michigan 48109, U.S.A.
}

Received 18 March 1977; accepted 10 June 1977

This study examines the effect of FSH, testosterone and estradiol on testicular LH receptors and in vitro testicular responsiveness to $\mathrm{LH}$ in immature rats under various conditions. FSH treatment of 15-day-old immature rats significantly increased the number of $L H$ receptors but did not alter testicular responsiveness. FSH treatment of hypophysectomized immature rats increased the number of $\mathbf{L H}$ receptors and markedly increased testicular responsiveness. Treatment of hypophysectomized rats with testosterone proprionate for 4 days, followed by a 5 -day treatment with $\mathrm{FSH}$, enhanced the effect of FSH on the number of $\mathrm{LH}$ receptors but did not increase the effect of FSH on testicular responsiveness. In contrast, treatment with estradiol for 4 days before FSH treatment had no effect on the FSH-induced increase in LH receptors but completely inhibited the FSH-induced increase in testicular responsiveness. These observations suggest that during male sexual maturation (1) regulation of LH receptors is distinct from regulation of testicular responsiveness to $\mathrm{LH},(2)$ estradiol may be a factor in the regulation of testicular responsiveness to LH, and (3) testosterone may enhance the FSH-induced increase of LH receptors.

Keywords: testosterone; $17 \beta$-estradiol; hypophysectomized immature male rat; follitropin; lutropin.

Factors involved in the development of lutropin (LH) sensitivity of Leydig cells during maturation have not been elucidated fully. Odell et al. $(1973,1974)$ sug* gested that follitropin (FSH) plays a major role in the development of testicular responsiveness to LH (stimulation of testosterone synthesis). Their studies indicated that testicular responsiveness to $\mathrm{LH}$ progressively increases during maturation and that this responsiveness is conditioned by previous exposure of the immature testis to FSH. Serum FSH concentrations in male rats are very low until day 22 . A sharp

\footnotetext{
* This investigation was supported by NIH Grant HD-08358.

** Present address: Department of Medicine, Stanford University, Stanford, California 94305, U.S.A.

† To whom reprint requests should be addressed.
} 
rise in serum FSH occurs between days 22 and 32 followed by a slow steady decline (Payne et al., 1977). Odell et al. (1974) reported that during sexual maturation in the rat testicular responsiveness to LH administration exhibited the sharpest increase between days 21 and 41 . If exposure of the testis to high levels of FSH is responsible for induction of testicular sensitivity to $\mathrm{LH}$, then administration of FSH prior to the sharp endogenous rise should induce LH sensitivity. To test this possibility, the effect of FSH administration to 15-day-old male rats was examined.

The mechanism by which FSH exerts its effect on Leydig cell responsiveness has not been ascertained. We recently reported that in the immature rat FSH treatment initiated 5 days after hypophysectomy increased both $\mathrm{LH}$ receptors and $\mathrm{LH}$-sensitive testosterone synthesis (Chen et al., 1976). LH-sensitive testicular response was increased to a greater extent than would be expected from the increase in the number of LH receptors. A similar observation was reported by Odell and Swerdloff (1975). It thus appears unlikely that the change in testicular sensitivity to LH in the immature rat can be attributed solely to increased numbers of LH receptors. It is possible that changes in the gonadal steroid milieu may influence testicular responsiveness to LH. It was recently reported that FSH stimulates estradiol synthesis from testosterone in Sertoli cells from immature rat testes (Dorrington and Armstrong, 1975). To evaluate the role of estradiol and testosterone in the induction of testicular responsiveness to $\mathrm{LH}$ and in regulation of $\mathrm{LH}$ receptors, the effect of these steroids per se or in combination with FSH was investigated.

\section{MATERIALS AND METHODS}

Sprague-Dawley rats hypophysectomized at day 20 were obtained from Hormone Assay Ltd. Rats, 14 days old, were obtained from Holtzman Co. Rats were kept with their mothers until 20 days of age. All treatments were given by subcutaneous injections twice daily at 08.00 and at $18.00 \mathrm{~h}$. NIH-FSH-SI l, biological potency $1.15 \times$ NIH-FSH-S1, $<0.01 \times$ NIH-LH-S1 or NIH-LH-S19, biological potency $1 \times$ NIH-LH-S1, $<0.05 \times$ NIH-FSH-S1 were administered in $0.1 \mathrm{ml}$ saline. Steroids were administered in $0.1 \mathrm{ml}$ propylene glycol.

FSH was administered twice daily for 6 days with either 40 or $80 \mu \mathrm{g} \mathrm{FSH/day}$ starting at 15 days of age in intact rats. All treatments of hypophysectomized rats were initiated 5 days after surgery. The following regimens of steroids, FSH or LH were employed: (1) Estradiol $0.2 \mathrm{mg} /$ day, or testosterone propionate $2 \mathrm{mg} /$ day, for 4,7 or 9 days. Higher doses of estradiol $(2 \mathrm{mg} /$ day) were lethal. Control rats received the same volume of propylene glycol for the appropriate period of time. (2) Propylene glycol $0.1 \mathrm{ml}$ for 4 days, followed by 5 days of $40 \mu \mathrm{g} \mathrm{FSH} /$ day or $2 \mu \mathrm{g} \mathrm{LH} /$ day (designated as $\mathrm{P}_{4} F_{5}, P_{4} \mathrm{~L}_{5}$ ). (3) Estradiol $0.2 \mathrm{mg} /$ day for 4 days, or testosterone propionate $2 \mathrm{mg} /$ day for 4 days, followed by 5 days of FSH $40 \mu \mathrm{g} /$ day $\left(\mathrm{E}_{4} \mathrm{~F}_{5}, \mathrm{~T}_{4} \mathrm{~F}_{5}\right)$. Control rats received propylene glycol and saline for the appropriate periods of time $\left(\mathrm{P}_{4} \mathrm{~S}_{5}\right)$. (4) FSH $40 \mu \mathrm{g} /$ day for 9 days and $\mathrm{FSH}$ for 10 days with 
simultaneous injections of testosterone propionate during the last 5 days of FSH $\left(\mathrm{F}_{9}\right.$ and $\mathrm{F}_{10}{ }^{\mathrm{T}} 5$ ).

Animals were killed by decapitation at the appropriate time and testes removed and weighed. One testis was used to quantitate the amount of LH receptors by determining specific binding of a saturating concentration of $\left[{ }^{125} \mathrm{I}\right] \mathrm{hCG}$ to a $20,000 \mathrm{~g}$ crude membrane fraction. Testes were homogenized in $0.25 \mathrm{M}$ sucrose buffered with $0.05 \mathrm{M}$ HEPES, $\mathrm{pH} 7.4$ (HS). The homogenate was centrifuged for 30 min at $20,000 \mathrm{~g}$. The $20,000 \mathrm{~g}$ pellet was resuspended in $1 \mathrm{ml}$ of HS. Aliquots of $0.1 \mathrm{ml}$ were incubated in a total volume of $0.2 \mathrm{ml}$ of HS containing $0.1 \% \mathrm{BSA}$, $5 \mathrm{mM} \mathrm{CaCl}{ }_{2}$ (HSB-Ca) and $100,000 \mathrm{cpm}\left[{ }^{125} \mathrm{I}\right] \mathrm{hCG}(\sim 60,000 \mathrm{cpm} / \mathrm{ng}$ ), and $100-$ fold excess of radioinert hCG in tubes in which nonspecific binding was determined. Incubations were carried out at $34^{\circ} \mathrm{C}$ for $1.5 \mathrm{~h}$. Reactions were stopped by addition of $1 \mathrm{ml}$ of ice-cold HSB.Ca. Hormone-bound testicular fractions were collected by centrifugation at $20,000 \mathrm{~g}$ for $30 \mathrm{~min}$. The supernatant was removed and the $20,000 \mathrm{~g}$ pellet was washed 2 more times with cold HSB-Ca. Radioactivity in each tube was determined by an automatic gamma spectrometer. Specific binding was calculated as the difference between binding in the presence and absence of excess radioinert $\mathrm{hCG}$ and expressed as cpm per testis.

For determination of testicular responsiveness to $\mathrm{LH}$, half of the contralateral testis from each rat was incubated in a Krebs-Ringer bicarbonate buffer (pH 7.4) with $2 \mathrm{mg}$ glucose/ml in the absence of LH and the other half in the presence of a saturating dose of rat $\mathrm{LH}(10 \mathrm{ng} / \mathrm{ml}$, Payne et al., 1977). Incubations were performed for $4 \mathrm{~h}$ at $34^{\circ} \mathrm{C}$ under $95 \% \mathrm{O}_{2}: 5 \% \mathrm{CO}_{2}$. At the end of incubation [ ${ }^{3} \mathrm{H}$ ]testosterone was added to monitor for losses. Testes plus media were homogenized and 3 vol. absolute ethanol were added. The mixture was stored at $-10^{\circ} \mathrm{C}$ for subsequent extraction of testosterone and quantification by radioimmunoassay as described previously (Payne et al., 1977). Testicular responsiveness to LH is expressed as the difference in testosterone production, $\Delta T$, with and without added $L H$.

One-way analysis of variance or Student's $t$-test was used to determine whether differences between means were significant. Separate treatment groups were considered significantly different if a $P$ value $<0.01$ was obtained, except where indicated otherwise.

\section{RESULTS}

\section{Effect of FSH on $L H$ receptors and $L H$ responsiveness in testes of intact immature rats}

The effect of FSH treatment on testicular weight, $\left[{ }^{125} \mathrm{I}\right] \mathrm{hCG}$ binding and in vitro testicular responsiveness to $\mathbf{L H}$ was examined in intact immature rats. Results observed in rats treated with FSH for 6 days either at $40 \mu \mathrm{g} /$ day or at $80 \mu \mathrm{g} /$ day starting at age 15 days are presented in fig. 1.

FSH treatment resulted in a significant increase in $\mathrm{LH}$ receptor content per 


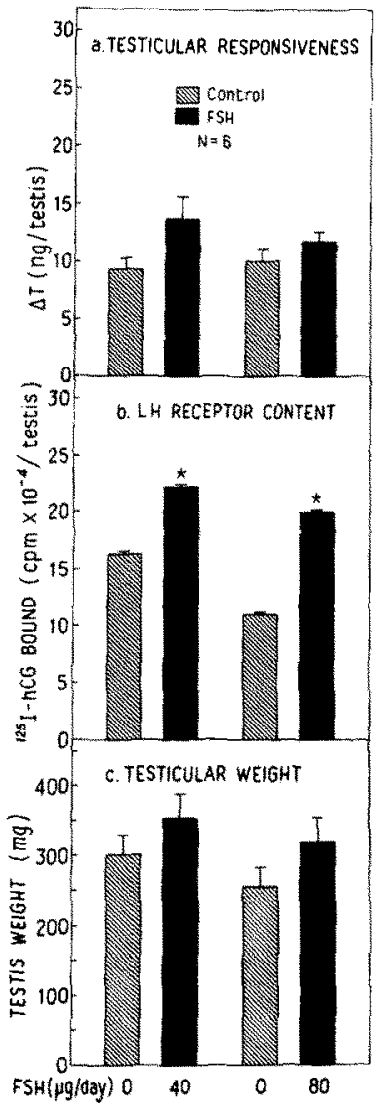

Fig. 1 .

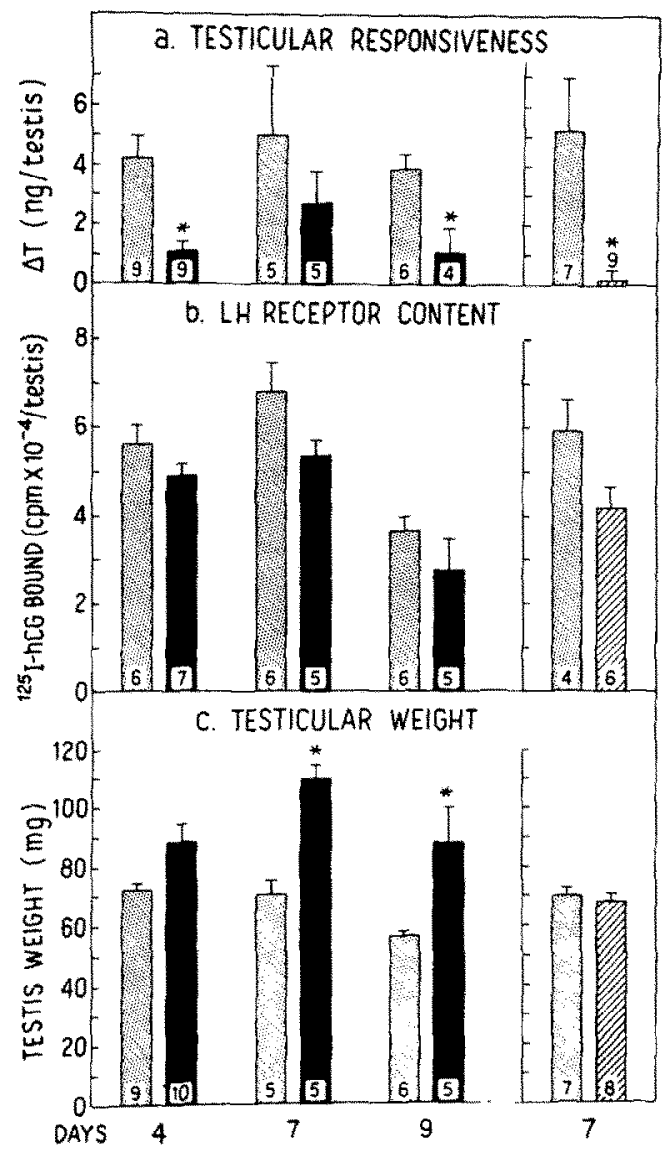

Fig. 2.

Fig. 1. Effect of FSH treatment on testicular function in 15-day-old intact rats. FSH was administered twice daily starting at age 15 days. In experiment $\mathrm{I}$, rats received either $40 \mu \mathrm{g}$ FSH/day or $0.2 \mathrm{ml}$ saline; in experiment $\mathrm{I}$, animals received $80 \mu \mathrm{g} \mathrm{FSH} /$ day or $0.2 \mathrm{ml}$ saline. Each bar represents the mean $\pm \mathrm{SE}$ of 6 rats $(\mathrm{n}=6)$. ${ }^{*} P<0.01$. (a) Testicular responsiveness, expressed as the difference in testosterone production with and without added LH $(\Delta T, \mathrm{ng} /$ testis). (b) LH receptor content, expressed as specifically bound $\left[{ }^{125} 1\right] \mathrm{hCG}$ (cpm/testis). (c) Testicular weight in mg.

Fig. 2. Effect of estradiol or testosterone treatment on testicular function in the hypophysectomized immature rat. Rats were hypophysectomized at day 20 . Steroid treatment was initiated 5 days after hypophysectomy and administered twice daily for the indicated number of days. Dotted bars: control rats received $0.2 \mathrm{ml} /$ day propylene glycol; solid bars: testosterone propionate-treated rats received $2 \mathrm{mg} /$ day; hatched bars: estradiol-treated rats received $0.2 \mathrm{mg}$ / day. Each bar represents mean $\pm S E$. Numbers inside bars represent number of rats. For details of (a), (b) and (c) see legend to fig. $1 .{ }^{*} P<0.01$. 
testis, but did not significantly increase testicular weight or alter testicular responsiveness to $\mathbf{L H}$.

Effect of testosterone and estradiol on $L H$ receptors and $L H$ responsiveness in testes of hypophysectomized rats

To examine the effects of gonadal steroids on $\mathrm{LH}$ receptor content and in vitro testicular responsiveness to $\mathrm{LH}$, testosterone or estradiol were administered for 4,7 or 9 days to 25 -day-old rats hypophysectomized 5 days previously. The results of this experiment are presented in fig. 2 . Testosterone treatment at $2 \mathrm{mg} /$ day resulted in a significant increase in testicular weight but had no significant effect on LH receptor content per testis when compared to propylene glycol injected control rats. In contrast to the effect of testosterone on testicular weight and $\mathrm{LH}$ receptor content, testosterone treatment resulted in a significant decrease in testicular responsiveness to LH following 4 and 9 days of treatment. A decrease in testicular responsiveness to $\mathrm{LH}$ is also observed after 7 days of treatment however, because of the large individual variation in this group of rats the observed decrease was not statistically significant. In testes from testosterone-treated rats, in vitro testosterone synthesis in the absence of LH was not decreased (data not shown).

The effect of estradiol treatment on testicular weight, $\left[{ }^{125} \mathrm{I}\right] \mathrm{hCG}$ binding and testicular responsiveness to $\mathrm{LH}$ is also presented in fig. 2 . No significant differences were observed whether rats were treated for 4 or 7 days with estradiol. Therefore the data for the two periods of treatment are combined and illustrated in fig. 2 . Treatment with estradiol $(0.2 \mathrm{mg} /$ day $)$ for 4 or 7 days did not have an effect on testicular weight but resulted in a slight decrease in LII receptor content per testis $(P<0.05)$. However, treatment with estradiol completely prevented LH stimulation of testosterone synthesis (fig. 2).

Effect of testosterone or estradiol on FSH-induced increase in $L H$ receptors and $L H$ responsiveness in testes of hypophysectomized rats

Hypophysectomized rats were treated with propylene glycol, testosterone or estradiol for 4 days followed by 5-day treatment with FSH. Another group of rats was treated for 9 days with FSH or 10 days with FSH plus testosterone during the last 5 days of treatment. Control rats received propylene glycol and saline as described under Materials and Methods. Results of this experiment are illustrated in fig. 3. FSH treatment for 5 or 9 days resulted in an increase in testicular weight, in receptor content per testis and in testicular responsiveness to $\mathrm{LH}$ (fig. $3, \mathrm{P}_{4} \mathrm{~S}_{5}$ vs. $\mathrm{P}_{4} \mathrm{~F}_{5}$ and $\mathrm{F}_{9}$ ). When animals are treated for 4 days with testosterone followed by 5-day treatment with FSH, LH receptor content/testis was significantly increased $(P<0.025)$ compared to rats treated with propylene glycol followed by FSH for 5 days $\left(\mathrm{P}_{4} \mathrm{~F}_{5}\right.$ vs. $\left.\mathrm{T}_{4} \mathrm{~F}_{5}\right)$. Pretreatment with testosterone for 4 days followed by a 5-day treatment with FSH, however, did not increase testicular responsiveness to $\mathrm{LH}$ compared to either 5 or 9 days of treatment with FSH (fig. $3, \mathrm{~T}_{4} \mathrm{~F}_{5}$ vs. $\mathrm{P}_{4} \mathrm{~F}_{5}$ or $\mathrm{F}_{9}$ ). When testosterone was administered for 7 days instead of 4 days prior to 5 


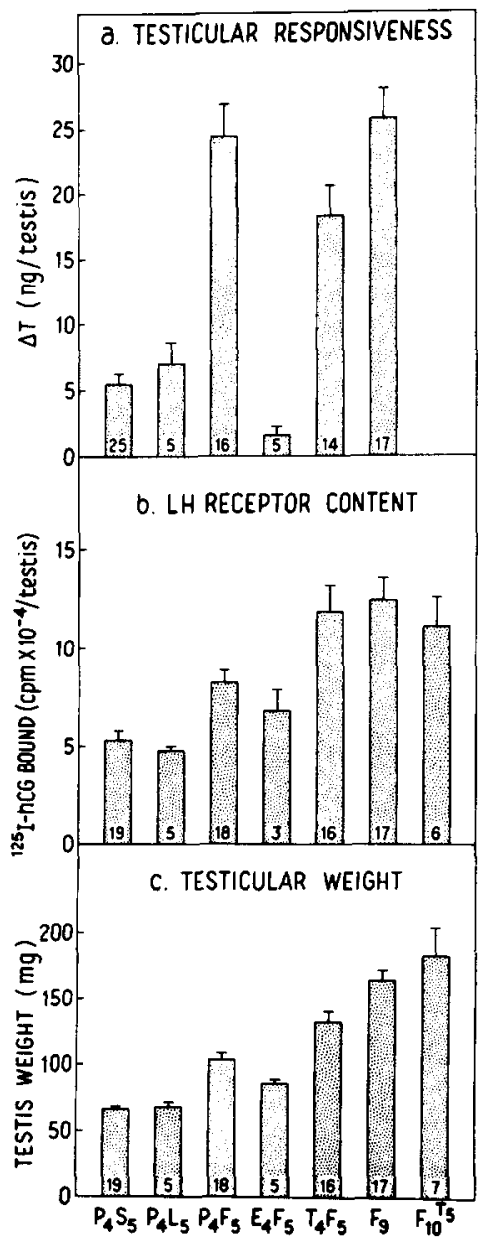

Fig. 3. Effect of sequential treatment of steroids and gonadotropins on testicular function in the immature hypophysectomized rat. Rats were hypophysectomized on day 20 . Treatments were initiated 5 days later and administered twice daily as follows: $\mathrm{P}_{4} \mathrm{~S}_{5}$, propylene glycol $0.2 \mathrm{ml} /$ day for 4 days followed by saline $0.2 \mathrm{ml} /$ day for 5 days; $\mathrm{P}_{4} \mathrm{~L}_{5}$, propylene glycol $0.2 \mathrm{ml} /$ day for 4 days followed by $\mathrm{LH} 2 \mu \mathrm{g} /$ day for 5 days; $\mathrm{P}_{4} \mathrm{~F}_{5}$, propylene glycol $0.2 \mathrm{ml} /$ day for 4 days followed by FSH $40 \mu \mathrm{g} /$ day for 5 days; $E_{4} F_{5}$, estradiol $0.2 \mathrm{mg} /$ day for 4 days followed by FSH $40 \mu \mathrm{g} /$ day for 5 days; $T_{4} F_{5}$, testosterone propionate $2 \mathrm{mg} /$ day for 4 days followed by FSH $40 \mu \mathrm{g} /$ day for 5 days; F9, FSH $40 \mu \mathrm{g} /$ day for 9 days; $F_{10}{ }^{\mathrm{T} 5}$, FSH $40 \mu \mathrm{g} /$ day for 10 days with simultaneous treatment of testosterone propionate $2 \mathrm{mg} /$ day during the last 5 days of FSH treatment. Each bar represents mean $\pm \mathrm{SE}$. Numbers inside bars indicate the number of rats. One-way analysis of variance was employed to compare the differences among groups. The levels of significance are presented in the text. For details of (a), (b) and (c) see legend to fig. 1. 
days of FSH administration testicular responsiveness to $\mathrm{LH}$ did not change, but the 7-day pretreatment with testosterone had a greater enhancing effect on FSH-induced LH receptors than the 4-day treatment (data not shown). No difference in in vitro testosterone synthesis was observed in the absence of LH $(2.91 \pm 0.31 \mathrm{ng} /$ testis for $P_{4} F_{5}$ vs. $2.98 \pm 0.53$ for $T_{4} F_{5}$ ). Treatment of rats with testosterone during the last 5 days of FSH treatment had no effect on either testicular weight or $\left[{ }^{125} \mathrm{I}\right]$ hCG binding per testis compared to FSH treatment alone (fig. $3, F_{10} T_{5}$ vs. $F_{9}$ ). In contrast, treatment with estradiol for 4 days followed by 5 days of FSH treatment had no effect on either testicular weight or $\left[{ }^{125} \mathrm{I}\right] \mathrm{hCG}$ binding/testis. However, treatment with estradiol before FSH treatment not only reversed the FSH-induced effect on testicular responsiveness to $\mathrm{LH}$, but resulted in a marked decrease in testicular responsiveness compared to saline-treated controls (fig. $3 . \mathrm{E}_{4} \mathrm{~F}_{5}$ vs. $\mathrm{P}_{4} \mathrm{~F}_{5}$, $\mathrm{E}_{4} \mathrm{~F}_{5}$ vs. $\mathrm{P}_{4} \mathrm{~S}_{5}$ ). Treatment of rats with $2 \mu \mathrm{g} \mathrm{LH} /$ day for 5 days had no effect on any of the parameters studied (fig. $3, \mathrm{P}_{4} \mathrm{~L}_{5}$ vs. $\mathrm{P}_{4} \mathrm{~S}_{5}$ ).

\section{DISCUSSION}

The present study demonstrates that FSH treatment of immature rats prior to the endogenous rise in serum FSH resulted in a significant increase in LH receptors. The FSH-induced increase in $\mathrm{LH}$ receptors per testis was not just a reflection of an increase in testicular weight since the increase in testicular weight was $17 \%$ and $25 \%$ while receptors per testis increased $36 \%$ and $85 \%$ in rats receiving 40 and $80 \mu \mathrm{g}$ FSH/day, respectively. Whether the higher percentage increase in $\mathrm{LH}$ receptor per testis in animals treated with the larger dose of FSH reflects a dose-dependent increase is difficult to ascertain since the data represent results from two separate experiments. In marked contrast to the effect of FSH in immature hypophysectomized rats (fig. $3 a, \mathrm{P}_{4} \mathrm{~F}_{5}$ vs. $\mathrm{P}_{4} \mathrm{~S}_{5}$ ), FSH treatment of 15 -day-old rats did not result in a significant increase in testicular responsiveness to $L H$. This absence of an FSH effect on testicular responsiveness in the presence of a stimulatory effect on LH receptor content per testis suggests the possibility that intracellular factors in testes from intact rats may inhibit the increase in testicular responsiveness which was observed in testes from FSH-treated hypophysectomized rats. Results from the present investigation suggest that estradiol may be the intracellular factor which inhibits FSH-induced testicular responsiveness to $\mathrm{LH}$, without having a similar effect on LH receptors per testis. Both estradiol and testosterone treatments in the hypophysectomized immature rat brought about inhibition of LH-sensitive testicular responsiveness without a significant effect on LH receptor content. This inhibitory action of the steroids on testicular responsiveness to LH is not mediated via the pituitary since this effect was observed in hypophysectomized rats. Previous studies on estradiol administration to intact mice and rats suggested that observed decreases in serum testosterone were due to a direct effect of estradiol on the testis (Samuels et al., 1969; Chowdhury et al., 1974; Moger, 1976). Estradiol or testoster- 
one probably act in the testis by inhibition of steroid-metabolizing enzymes. We recently reported (Murono and Payne, 1976) that both estradiol and testosterone inhibit interstitial tissue 17-ketosteroid reductase, the enzyme which catalyzes the final step in testosterone synthesis. Estradiol was found to be a much more potent inhibitor of this enzyme activity than was testosterone, which correlates with our results on the inhibitory action of these two steroids on testicular responsiveness to LH.

A noteworthy observation in the present study was the effect testosterone and estradiol had in hypophysectomized rats on the FSH-induced stimulation of LH receptor content per testis and on LH-sensitive testicular responsiveness. While testosterone treatment per se had no effect on $\mathrm{LH}$ receptor content per testis and decreased testicular responsiveness to $\mathrm{LH}$, testosterone treatment followed by FSH treatment enhanced the FSH-induced effect on LH receptors and did not alter testicular responsiveness to $\mathrm{LH}$. This suggests that in the intact rat during male sexual maturation, endogenous testosterone may enhance the FSH effect on LH receptor content. In contrast, estradiol treatment followed by FSH treatment does not change the FSH-induced increase in LH receptors per testis, but markedly inhibits the FSH-induced increase in testicular responsiveness to LH. It should be noted that this inhibition of LH-sensitive testosterone synthesis was observed 5 days after the last administration of estradiol. This suggests that estradiol inhibition of FSH-induced testicular responsiveness to $\mathrm{LH}$ must involve a mechanism other than direct inhibition of testosterone-synthesizing enzymes. A specific cytoplasmic and nuclear receptor protein for estradiol in rat testes interstitial tissue has been demonstrated by Brinkman et al. (1972), Mulder et al. (1973) and van Beurden-Lamers et al. (1974), suggesting that modification of transcription may be another mechanism by which estradiol inhibits FSH-induced LH-sensitive testosterone synthesis.

Dorrington and Armstrong (1975) recently reported that FSH stimulated synthesis of estradiol from testosterone by approximately 12 -fold in Sertoli cells isolated from 20-day-old rat testes and maintained in primary culture. In a later communication these authors reported that cultured Sertoli cells from 5-day-old rats synthesized considerably more estradiol in the presence of FSH than cells from 20-day-old rats and that cells from rats between 30 and 40 days of age did not synthesize detectable estradiol in the presence of FSH (Dorrington et al., 1976). These observations and those in the present study suggest that intratesticular estradiol levels during early sexual maturation may inhibit testicular responsiveness to LH. Increased testicular responsiveness observed later in maturation (Odell et al., 1974; Payne et al., 1977) may result in part from decreased estradiol synthesis. In preliminary studies we have found that estradiol concentrations in $\mathrm{pg} / 100 \mathrm{mg}$ testicular tissue were $15.7 \pm 1.9$ (mean \pm SE) in 16-day-old, $6.2 \pm 1.3$ in 22-day-old and $3.5 \pm 0.57$ in 30 -day-old rats.

It would appear from the observations in the present study that regulation of testicular responsiveness to $\mathrm{LH}$ is distinct from regulation of $\mathrm{LH}$ receptor content per testis. The data also suggest that development of Leydig cell function during sexual maturation may be a result of both steroidal and gonadotropin action. 


\section{ACKNOWLEDGMENTS}

We thank Carol Craig for expert technical assistance and Dr. Robert P. Kelch and Brenda Johnson for the estradiol determinations. We also thank Dr. A.F. Parlow for the rat LH, NIAMDD-Rat LH-I-3, and NIAMDD for supplying the NIH-FSH-S11 and NIH-LH-S19.

\section{REFERENCES}

Brinkman, A.O., Mulder, E., Lamers-Stahlhofen, G.J.M., Mechielsen, M.J. and van der Molen, H.J. (1972) FEBS Lett. 26, 301.

Chen, Y.-D.I., Payne, A.H. and Kelch, R.P. (1976) Proc. Soc. Exp. Biol. Med. 153, 473.

Chowdhury, M., Tcholakian, R. and Steinberger, E. (1974) J. Endocrinol. 60, 375.

Dorrington, J.H. and Armstrong, D.T. (1975) Proc. Natl. Acad. Sci. U.S.A. 72, 2677.

Dorrington, J.H., Fritz, I.B. and Armstrong, D.T. (1976) Vth International Congress of Endrocrinology, Abst. 767, p. 316.

Moger, W.H. (1976) Biol. Reprod. 14, 115.

Mulder, E., Brinkmann, A.O., Lamers-Stahthofen, G.J.M. and van der Molen, H.J. (1973) FEBS Lett. $31,131$.

Murono, E.P. and Payne, A.H. (1976) Biochim. Biophys. Acta $450,89$.

Odell, W.D., Swerdloff, R.S., Jacobs, H.S. and Hescox, M.A. (1973) Endocrinology 92, 160.

Odell, W.D., Swerdloff, R.S., Bain, J., Wollesen, F. and Grover, P.K. (1974) Endocrinology, 95, 1380.

Odell, W.D. and Swerdloff, R.S. (1975) J. Steroid Biochem. 6, 853.

Payne, A.H., Kelch, R.P., Murono, E.P. and Kerlan, J.T. (1977) J. Endocrinol. $72,17$.

Samuels, L.T., Uchikawa, T., Zain-ul-Abedin, M. and Huseby, R.A. (1969) Endocrinology 85, 96.

Van Beurden-Lamers, W.M.O., Brinkmann, A.O., Mulder, E. and van der Molen, H.J. (1974) Biochem. J. 140, 495. 